\title{
Islam di Kalimantan Selatan pada Abad Ke-15 sampai Abad Ke -17
}

\author{
Muhammad Azmi \\ Staf Pengajar Program Konsentrasi Pendidikan Sejarah Universitas Mulawarman \\ azmie.yc@gmail.com
}

\begin{abstract}
The theory of the process of the coming of Islam to Indonesia have been assessed and expressed by many experts. Stages of the process in Nusantara is divided into three phases, the process of arrival in the 7th century, the deployment process in the 11th century and the process of development in the 13th century. It also gives influence on the process of arrival, distribution and development of Islam in South Kalimantan. This paper is a review of the literature that gives an overview on the islamization of the South Kalimantan covering the arrival, distribution and development at the 15th century until the 17th century.
\end{abstract}

Keywords: Islam, South Kalimantan, Banjar Sultanate

\begin{abstract}
ABSTRAK
Proses masuknya Islam ke Indonesia telah dinilai dan diungkapkan oleh banyak ahli. Tahapan proses di Nusantara terbagi menjadi tiga fase, yaitu proses kedatangan di abad ke-7, proses penyebaran di abad ke-11 dan proses perkembangan di abad ke-13. Hal ini juga memberi pengaruh pada proses kedatangan, penyebaran dan perkembangan Islam di Kalimantan Selatan. Tulisan ini adalah kajian pustaka yang berusaha memberikan gambaran tentang proses islamisasi Kalimantan Selatan meliputi kedatangan, penyebaran dan perkembangan Islam pada abad ke-15 sampai abad ke-17.
\end{abstract}

Kata Kunci: Islam, Kalimantan Selatan, Kesultanan Banjar

\section{PENDAHULUAN}

Berbagai teori tentang masuknya Islam ke Nusantara telah dikemukakan oleh para ahli. Secara umum, pendapat tersebut dapat dibagi dalam empat teori besar, yaitu Teori Gujarat, Teori Mekkah, Teori Persia, dan Teori Cina (Suryanegara, 2009: 99-102). Nor Huda (2007: 32) menggunakan istilah yang lebih umum untuk menyebutkan Gujarat dan Mekkah, yaitu India dan Arab. Menurut Daliman (2012: 35), secara umum pembabakan Islamisasi di Nusantara dapat dibagi dalam tiga babak, yaitu: masa kedatangan, proses penyebaran dan proses perkembangan.
Masa kedatangan Islam di Nusantara dimulai pada abad ke-7 berdasarkan pendapat dari para ahli tentang adanya pemukiman Ta-Shih di beberapa tempat di wilayah Sriwijaya. Rita Rose Di Meglio mendefinisikan Ta-Shih sebagai orang Islam yang berasal dari Arab atau Persia dan bukan orang Islam dari India. Selain itu, disebutkan pula dalam berita Jepang yang ditulis pada $748 \mathrm{M}$ menceritakan tentang perjalanan Pendeta Kanshin. Dalam berita tersebut diceritakan bahwa pada masa itu di Kanton berlabuh kapalkapal dari Posse dan Ta-shih Kuo. Rita Rose mendefinisikan Ta-shih sebagai 
orang Arab dan Po-sse sebagai orang Melayu (Daliman, 2012: 33).

Proses penyebaran Islam pada abad ke-11 di Nusantara ditandai dengan ditemukannya batu nisan makam Fatimah binti Maimun di Leran, Gresik berangka tahun 1082 M. Selain itu, sebuah batu berukir di daerah Lubuk Tua, pantai barat Sumatera menunjukkan pula kemungkinan bahwa Islam telah masuk ke Sumatera pada masa yang lebih tua lagi. Hal inilah yang menyebabkan beberapa ahli berpendapat bahwa Islam telah masuk ke Nusantara pada abad ke-7 (Daliman, 2012: 32).

Proses perkembangan Islam di Nusantara dimulai pada abad ke-13 sebagaimana yang didukung oleh banyak ahli berdasarkan fakta-fakta historis. Berita Marco Polo dari Venesia yang singgah di Samudera Pasai pada 1292 M dalam perjalanan pulang dari Cina dapat menjadi acuan dalam teori ini. Keterangan Marco Polo yang menyebutkan bahwa ia telah singgah di Sumatera dan menyebutkan bahwa Perlak telah dikenal sebagai sebuah kota Islam (Ricklefs, 2009: 4).

Para ahli berpendapat bahwa Kerajaan Samudera Pasai merupakan kerajaan Islam pertama di Nusantara di akhir abad ke-13. Bukti yang memperkuat pendapat ini adalah ditemukannya bukti-bukti arkeologis batu nisan makam Sultan Malik al Saleh berangka tahun $1297 \mathrm{M}$.

Berita Ibnu Bathuthah yang singgah di Samudera Pasai pada 1345 M dapat pula dijadikan acuan tentang perkembangan Islam pada abad ke-13. Dalam berita tersebut ia mendapati bahwa penguasa Samudera Pasai adalah seorang pengikut mazhab Syafi'i. Hal ini menegaskan bahwa keberadaan mazhab ini sudah berlangsung sejak lama, yang kelak akan mendominasi Indonesia (Bathuthah, 2012: 601). Namun, tidak menutup adanya kemungkinan bahwa ketiga mazhab Sunni lainnya, yaitu Mazhab Hanafi, Mazhab Maliki, dan Mazhab Hambali juga sudah masuk ke Nusantara pada masa-masa awal berkembangnya Islam.

\section{KEDATANGAN ISLAM DI KALIMANTAN SELATAN}

Kalimantan merupakan daerah yang dikenal memiliki hasil bumi yang melimpah. Hasil bumi dari Kalimantan yang menjadi incaran para pedagang Cina sejak 1400 Masehi adalah intan yang merupakan daerah penghasil satusatunya di Nusantara. Pada abad ke-15, pusat perdagangan intan di Kalimantan Selatan, seperti Tanjungpura dan Matan telah dikuasai oleh para pedagang Cina. Bahkan, pada saat Portugis masuk ke dalam bidang perdagangan di wilayah ini tidak dapat menggeser peranan 
pedagang Cina yang telah menguasai jalur perdagangan selama berabad-abad sebelumnya (Ideham, et al, 2003: 51).

Tome Pires (2014: 187-188) dalam Suma Oriental mendeskripsikan bahwa:

Kalimantan terdiri dari banyak pulau, baik besar maupun kecil yang hampir seluruhnya ditinggali oleh orang Pagan, kecuali pulau utamanya yang ditinggali oleh orang Moor setelah belum lama rajanya menjadi seorang Moor. Mereka tampaknya sangat lihai berdagang yang sebagian besar merupakan pria-pria berkedudukan menengah. Tempat ini merupakan penghasil daging, ikan, beras dan sagu yang melimpah.

Deskripsi tersebut kemungkinan terdapat sedikit kekeliruan karena luasnya Pulau Kalimantan yang dibelah beberapa sungai besar, sehingga Tome Pires menganggap bahwa daerah tersebut adalah pulau yang berbeda. Sungai-sungai besar yang besar di Kalimantan bagian selatan adalah Barito, Kapuas, Kahayan dan seluruh anak sungainya. Hal ini dapat dilihat dari deskripsinya bahwa Tanjungpura (Tanjompura), Laue, Kadawangan (Quedomdoam), Sampit, (Samper), Kotabaru (Cate), dan Pamukan (Pamuca) sebagai pulau yang terpisah. Padahal dalam kenyataannya, empat daerah pertama berada di Pulau Kalimantan dan dua sisanya berada di Pulau Laut.

Istilah pagan merupakan sebutan bagi penyembah berhala. Dalam hal ini yang dimaksud dengan pagan kemungkinan adalah mereka belum memeluk satu agama pun karena masih memegang teguh sistem kepercayaan nenek moyang. Adapun sebutan Moor adalah sebutan bagi pemeluk agama Islam yang mengacu pada gelar bagi muslim di daerah Spanyol dan Portugis. Tome Pires yang berkebangsaan Portugal menggunakan istilah ini dalam Suma Oriental untuk menyebut orang muslim. Moor adalah orang Muslim dari zaman pertengahan yang tinggal di $\mathrm{Al}$-Andalus (Semenanjung Iberian termasuk Spanyol dan Portugis zaman sekarang) dan juga Maroko dan Afrika barat, yang budayanya disebut Moorish. Kata ini juga digunakan di Eropa untuk menunjuk orang yang memiliki keturunan Arab atau Afrika. Nama Moor berasal dari suku kuno Maure dan kerajaan Mauritania (Wikipedia, 2016)

Deskripsi yang dikemukakan oleh Tome Pires tentang "raja yang menjadi seorang Moor" secara harfiah dapat didefinisikan sebagai raja yang memeluk agama Islam. Kemungkinan deskripsi tersebut mengacu pada masuk Islamnya Pangeran Samudera setelah mengalahkan Pangeran Tumanggung. Kemenangan tersebut didapatkan ketika mendapatkan bantuan dari Demak dalam perebutan tahta kekuasaan Kerajaan Nagara Daha. Dalam hal ini, yang dimaksud dengan "seorang raja menjadi 
Moor" adalah Pangeran Samudera yang kemudian mendapatkan gelar Sultan Suriansyah.

Kedatangan Islam di Kalimantan tentunya tidak luput dari jaringan Islamisasi Nusantara. Tidak dapat diketahui dengan pasti kapan masuknya Islam ke Kalimantan Selatan. Namun, hal tersebut tidak lepas dari jaringan perdagangan Nusantara yang salah satu penggeraknya adalah para pedagang yang telah memeluk agama Islam. Tidak mustahil bahwa diantara sekian banyak pedagang yang pernah singgah di Banjarmasin merupakan pedagang muslim dan pernah tinggal di kota pelabuhan ini.

Tome Pires (2014: 188-189) menggambarkan bahwa:

Para pedagang yang berasal dari Kalimantan memerlukan waktu satu bulan untuk berangkat ke Malaka guna membawa barang dagangan dan kembali ke Kalimantan dalam waktu satu bulan pula. Mereka biasanya membawa emas, lilin, madu, nasi, dan sagu ke Malaka dan membawa pulang berbagai jenis kain, berbagai jenis manik-manik dari Cambay yang terbuat dari kaca dan mutiara, serta gelang dari kuningan ke Kalimantan.

Berdasarkan deskripsi dari Tome Pires tersebut, sangat mungkin bahwa dalam perjalanan selama dua bulan tersebut terdapat para pedagang muslim yang membawa barang dagangan langsung ke Kalimantan dan kemudian menetap disana sambil menunggu waktu untuk pulang ke Malaka enam bulan kemudian. Hal ini dikarenakan adanya angim musim (muson) Barat dan Timur yang bertiup secara bergantian setiap enam bulan sekali. Angin Muson Barat bertiup dari arah Asia ke Australia yang dimanfaatkan untuk kembali dari Malaka ke Kalimantan, sedangkan Angin Muson Timur bertiup dari Australia ke Asia yang dimanfaatkan untuk mengangkut barang dagangan dari Kalimantan ke Malaka.

Dalam deskripsi tersebut, kemungkinan besar yang dimaksud dengan nasi adalah beras, sebab nasi tidak akan bertahan lama dalam satu bulan perjalanan dari Kalimantan menuju Malaka. Berbeda halnya dengan beras yang masih tetap awet dalam waktu yang cukup lama. Kemungkinan besar ada kesalahan penerjemahan kata "rice" yang dapat diartikan padi, beras atau nasi. Dalam hal ini, terjemahan beras lebih sesuai untuk digunakan dalam mengartikan kata tersebut.

Sebelum masuknya Islam ke Kalimantan Selatan, daerah ini telah mendapatkan pengaruh Hindu yang ditandai dengan berdirinya Kerajaan Negara Dipa yang menjadi cikal bakal kerajaan Hindu pertama di Kalimantan Selatan. Dalam Hikayat Lambung Mangkurat atau Hikayat Banjar disebutkan bahwa di daerah Kalimantan Selatan telah berdiri sebuah kerajaan 
bercorak Hindu yang bernama Negara Dipa yang berlokasi di sekitar Amuntai dan kemudian dilanjutkan dengan Negara Daha yang berlokasi di sekitar Nagara sekarang (Ideham, et al, 2003: $51)$.

Menurut Hikayat Lambung Mangkurat, Negara Dipa didirikan oleh Empu Jatmika, anak saudagar Mangkubumi dari Keling. Ia meninggalkan Keling dengan Prabayaksa yang diiringi oleh pengikutnya Tumenggung Tatahjiwa Arya Megatsari dan juru bahasa Wiramartas yang pandai berbagai bahasa. Mereka memasuki Sungai Barito dan meneruskan perjalanan melewati Sungai Negara. Berdasarkan amanat ayahnya sebelum meninggal, ia harus mencari dan menetap di daerah yang panas seperti bara api tetapi berbau harum layaknya bau pudak. Akhirnya, ia menemukan daerah tersebut yang terletak di pertemuan Sungai Negara dengan Sungai Amuntai (Usman, 1995: 2).

Di tempat situlah didirikan Candi Laras dan ia mendapatkan gelar "Maharaja di Candi". Gelar ini diberikan kepada Empu Jatmika dikarenakan ia bukanlah keturunan dari kasta Ksatria yang seharusnya menjadi raja dalam sebuah kerajaan Hindu. Ia hanyalah seorang pedagang yang termasuk dalam kasta Vaisya. Oleh karena itu, ia pun membuat patung dan menjadikannya sebagai raja, sedangkan ia hanyalah wakil dari patung "raja" tersebut dalam memerintah kerajaan yang ia bangun, yaitu Kerajaan Daha. Hal ini dilakukan agar tidak mendapatkan musibah karena melanggar aturan pengkastaan dalam agama Hindu.

Diceritakan pula bahwa Empu Jatmika juga membawa dua orang anaknya yang bernama Lambung Mangkurat dan Mpu Mandastana sampai ke Hujung Tanah. Selama kepemimpinannya, negara ini telah dikunjungi oleh para pedagang dari Cina, Johor, Aceh, Bugis, Makassar, Sumbawa, Bali, Jawa, Banten, Madura, Tuban, Makau dan Kaling (Ideham, et al, 2003: 37). Kemudian, Hikayat Banjar menceritakan tentang digantikannya Negara Dipa oleh negara baru yang bernama Negara Daha. Pusat kekusaan Negara Daha terletak di Muara Hulak dan Muara Bahan sebagai pelabuhannya. Pada masa ini, Muara Bahan telah banyak dikunjungi oleh para pedagang yang berasal dari Jawa, Melayu, Dayak, Cina, Bugis dan Makassar. Rakyat dari Negara Daha kebanyakan merupakan penduduk Negara Dipa. Negara Daha melakukan ekspansi kekuasaan sampai ke wilayah Sewa Agung, Bunyut, Karasikan, Balitung, Lawai dan Kotawaringin (Ideham, et al, 2003: 37). 
PENYEBARAN ISLAM DI KALIMANTAN SELATAN

Proses penyebaran Islam di Kalimantan Selatan akan berpusat pada seorang pewaris sah kerajaan Negara Daha yang bernama Raden Samudera. Ia dinobatkan menjadi Raja Banjar oleh Patih Masih, Muhur, Balit dan Kuwin (Poesponegoro dan Notosusanto, 1992: 86). Patih Masih hanyalah sebuah gelar bagi pemimpin dalam sebuah kelompok. Pada masa ini patih belum termasuk dalam struktur birokrasi kerajaan. Nama sebenarnya Patih Masih tak diketahui. Istilah Patih Masih berasal dari istilah Oloh Ngaju, yakni sebutan untuk orang Melayu atau Oloh Masi. Patih Masih tak lain dari Patih yang memerintah orangorang Melayu (Noor, 2011: 107).

Proses penyebaran Islam di Kalimantan Selatan secara terangterangan dimulai dengan kontak antara Pangeran Samudera dengan Kerajaan Demak. Pada saat itu, Pangeran Samudera meminta bantuan pasukan ke Demak untuk berperang melawan pamannya, Pangeran Tumenggung dalam merebut tahta kekuasaan Negara Daha. Pada saat itu, ia menghadapi bahaya yang berat yaitu kelaparan di kalangan pengikutnya. Atas usul Patih Masih, Pangeran Samudera meminta bantuan kepada Demak yang merupakan kerajaan terkuat setelah Majapahit. Dalam hal ini, Patih Balit diutus menghadap Sultan
Demak dengan membawa 400 penggiring dan 10 buah kapal (Usman, 1995: 2).

Setibanya di Demak, Patih Balit langsung menghadap Sultan Demak Trenggana dengan membawa sepucuk surat dari Pangeran Samudera. Surat tersebut ditulis dalam Bahasa Banjar dengan menggunakan Huruf ArabMelayu yang berbunyi sebagai berikut:

"Salam sembah putera andika Pangeran di Banjarmasin datang kepada Sultan Demak. Putera andika menantu nugraha minta tolong bantuan tandingan lawan sampean karena putera andika berebut kerajaan lawan parnah mamarina yaitu namanya Pangeran Tumenggung. Tiada duadua putera andika yaitu masuk mengula pada andika maka persembahan putera andika intan 10 biji, pekat 1.000 galung, tudung 1.000 buah, damar 1.000 kandi, jerangan 10 pikul dan lilin 10 pikul". (Clecrq, De Vroegtse Geschiedenis van Banjarmasin, 1877: 264 dalam Usman, 1995: 2223)

Ada dua hal yang menarik dalam surat tersebut. Pertama, penggunaan bahasa Arab-Melayu dalam penulisannya. Menurut A. Basuni dalam makalahnya pada Prasaran Seminar Sejarah Kalimantan Selatan berjudul Usaha Menggali Sejarah Masuknya Islam di Kalimantan Selatan pada 1976 mengatakan bahwa huruf Arab telah dikenal oleh Pangeran Samudera yang menunjukkan bahwa masyarakat Islam 
telah lama terbentuk di Banjarmasin. Lahirnya kepandaian membaca dan menulis huruf Arab memerlukan waktu yang cukup lama. Kedua, besarnya pemberian yang diberikan kepada Sultan Demak tentunya memerlukan penyandang dana yang sangat besar guna membeli semua barang tersebut. Dalam hal ini, kemungkinan besar Patih Masih adalah saudagar kaya yang mempunyai akses dalam perdagangan ke pedalaman Kalimantan (Ideham, 2003: 61).

Hubungan Banjar dan Demak telah terjalin dalam waktu yang lama, terutama dalam hubungan ekonomi perdagangan yang kemudian berlanjut dalam hubungan kemiliteran. Sultan Demak menyanggupi permintaan bala bantuan tersebut dengan syarat apabila menang, Pangeran Samudera dan pengikutnya mau memeluk agama Islam. Inilah awal dari penyebaran Islam secara terang-terangan yang dilakukan oleh Demak ke Kalimantan Selatan. Akhirnya, Pangeran Samudera berhasil mengalahkan Pangeran Tumenggung dan berhasil merebut Negara Daha dan pelabuhan Muara Bahan. Peristiwa ini terjadi pada 24 September 1526, yang kemudian diabadikan menjadi hari jadi Kota Banjarmasin.

Salah satu episode penting dalam proses Islamisasi di Kalimantan yang disebutkan dalam Hikayat Banjar adalah pembicaraan tentang hubungan Banjar dan Demak. Disebutkan dalam hikayat, bahwasanya Raja Banjar Raden Samudera telah ditasbihkan sebagai Sultan oleh Penghulu Demak dan oleh seorang Arab diberi gelar Sultan Suryanullah (Kartodirdjo, et al, 1975: 271 dalam Ideham, 2003: 63). Penghulu Demak yang diutus untuk mengislamkan Pangeran Samudera dikenal dengan nama Khatib Dayan. Melihat dari jabatan kepenghuluan Demak, maka pada masa 1521-1524 penghulu Demak dipegang oleh Penghulu Rahmatullah (Ideham, 2003: 63). Dengan demikian, Khatib Dayan bukanlah seorang penghulu Demak, tetapi hanyalah seorang utusan dari penghulu Demak yang bertugas untuk mengIslamkan Pangeran Samudera dan seluruh pengikutnya di Banjarmasin.

\section{KERAJAAN BANJAR DAN PERUBAHAN STRUKUR BIROKRASI}

Setelah kemenangan Pangeran Samudera dalam peperangan melawan Pangeran Tumenggung, ia mengosongkan Negara Daha dan memindahkan semua penduduknya ke Banjarmasin. Hal ini dilakukan karena memandang dari segi ekonomis negara. Pelabuhan Muara Bahan yang terletak sekitar $40 \mathrm{~km}$ dari muara Sungai Barito dengan melewati banyak anak sungai yang berkelok-kelok tentunya akan 
sangat memakan waktu bagi para pedagang untuk menuju kesana. Berbeda halnya dengan pelabuhan Banjarmasin yang berada tepat di muara Sungai Barito. Hal inilah yang menjadi pertimbangan Pangeran Samudera atau yang dikenal dengan Sultan Surianysah untuk memindahkan ibukota kerajaan ke Banjarmasin. Inilah salah satu tanda awal berdirinya Kesultanan Banjar.

Banjarmasin dikenal sebagai sebuah kota pelabuhan di Kalimantan, dimana Sungai Barito menjadi merupakan urat nadi pelayaran sungai di daerah Kalimantan bagian Selatan tersebut. Lokasi kota ini berada dalam wilayah yang langsung menghadap ke Pulau Jawa, sehingga menjadikan kota ini termasuk dalam jaringan perdagangan Nusantara. Banjarmasin yang terletak tepat di daerah muara pesisir Sungai Barito menjadikannya sebagai tempat para pedagang dari berbagai jaringan penjuru Nusantara, bahkan jaringan internasional untuk berlabuh. Tidak dapat dipungkiri bahwa letak Banjarmasin yang sangat strategis tersebut menjadikannya salah satu pelabuhan transito Nusantara, sekaligus menjadi pintu gerbang utama untuk melakukan perdagangan ke daerah pedalaman Kalimantan yang dikenal dengan hasil buminya.

Pada masa kepemimpinan Sultan Suriansyah, struktur kepemimpinan yang sebelumnya mengacu pada Kerajaan
Negara Daha yang identik dengan Hindu dirubah sesuai dengan tuntunan agama Islam. Beliau membuat struktur sebagai berikut: Mangkubumi, Mantri PangiwaPanganan, Mantri Jaksa, Tuan Panghulu, Tuan Khalifah, Khatib, Para Dipati dan Pra Pryai. Keputusan Sultan Surianyah ini merupakan suatu upaya untuk melakukan internalisasi agama Islam dalam struktur birokrasi Kerajaan Banjar (Khairuzzaini, 2011: 4-5).

Dalam struktur birokrasi yang baru ini, terdapat perbedaan perlakuan antara pembicaraan-pembicaraan mengenai hukum Islam dan hukum sekuler. Masalah yang menyangkut bidang agama Islam dibicarakan dalam suatu rapat/musyawarah yang terdiri dari Mangkubumi, Dipati, Jaksa, Khalifah dan Penghulu yang menjadi pemimpin dalam pembicaraan tersebut. Adapun masalahmasalah yang menyangkut hukum sekuler yang disebut hukum Dirgama, dibicarakan dalam rapat antara Raja, Mangkubumi, Dipati dan Jaksa yang menjadi pimpinan rapat. Adapun masalah yang menyangkut dengan tata urusan kerajaan merupakan pembicaraan antara Raja, Mangkubumi dan Dipati (Khairuzzaini, 2011: 5).

Dalam struktur birokrasi yang dibuat oleh Sultan Suriansyah tersebut kewenangan penghulu lebih tinggi dari Jaksa, sebab Penghulu mengurusi masalah yang menyangkut agama, 
sedangkan Jaksa mengurus masalah yang menyangkut dunia. Para Dipati, yang biasanya terdiri dari para saudara raja yang bertugas untk menemani dan membantu raja, kedudukan mereka terletak setelah Mangkubumi. Sistem politik dan pemerintah ini berlangsung sejak kepemimpinan Sultan Suriansyah sampai masa kepemimpinan Sultan Musta'in Billah pada permulaan abad ke17 (Khairuzzaini, 2011: 5).

\section{PENUTUP}

Proses Islamisasi Kalimantan Selatan dapat dibagi dalam tiga periode, yaitu masa kedatangan, masa penyebaran dan masa perkembangan. Masa kedatangan Islam di Kalimantan Selatan ditandai dengan terhubungnya jalur perdagangan Kalimantan dalam jaringan perdagangan Nusantara. Meskipun tidak diketahui secara pasti kapan masuknya Islam ke Kalimantan Selatan, tetapi dapat dipastikan bahwa Islam dapat masuk ke daerah tersebut dikarenakan adanya hubungan perdagangan Nusantara. Tidak menutup kemungkinan adanya para pedagang muslim diantara sekian banyak pedagang yang masuk ke Kalimantan Selatan yang pada masa itu masih di bawah pengaruh Kerajaan Hindu Negara Dipa dan Negara Daha.

Masa penyebaran Islam ditandai dengan permintaan bantuan Pangeran Samudera kepada Sultan Demak untuk membantu perlawanan terhadap Pangeran Tumenggung dalam perebutan tahta Kerajaan Negara Daha. Bantuan Sultan Demak tersebut dengan syarat masuk Islamnya Pangeran Samudera dan seluruh rakyatnya apabila dapat memetik kemenangan. Alhasil, Pangeran Samudera dapat merebut tahta Kerajaaan Negara Daha dan Penghulu Demak yang pada masa itu dijabat oleh Penghulu Rahmatullah mengutus Khatib Dayan untuk mengislamkan Pangeran Samudera dan seluruh pengikutnya. Pangeran Samudera diberi gelar Sultan Suryanullah.

Babak terakhir dalam proses Islamisasi di Kalimantan Selatan adalah internalisasi agama Islam dalam seluruh sendi kehidupan Kerajaan Banjar. Perubahan struktur birokrasi lama yang dipakai Kerajaan Negara Daha yang identik dengan Hindu dilakukan oleh Sultan Suriansyah. Raja pertama Kerajaan Banjar tersebut membuat struktur yang diisi oleh Mangkubumi, Mantri Pangiwa-Panganan, Mantri Jaksa, Tuan Panghulu, Tuan Khalifah, Khatib, Para Dipati dan Pra Pryai. Dalam struktur birokrasi tersebut diberlakukan perbedaan perlakuan antara masalah yang menyangkut agama Islam dan masalah yang menyangkut dengan hukum sekuler yang disebut hukum Dirgama. Sistem politik dan pemerintah ini berlangsung sejak kepemimpinan 
Sultan Suriansyah pada abad ke-16 sampai pada masa kepemimpinan Sultan Musta'in Billah pada permulaan abad ke17.

\section{REFERENSI}

Bathuthah, M. 2012. Rihlah Ibnu Bathuthah. Terj. Muhammad Muchson Anasy dan Khalifurrahman Fath. Jakarta: Pustaka al-Kautsar.

Daliman, A. 2012. Islamisasi dan Perkembangan Kerajaan-Kerajaan Islam di Indonesia. Yogyakarta: Penerbit Ombak.

Huda, N. 2007. Islam Nusantara: Sejarah Sosial Intelektual Islam di Indonesia. Yogyakarta: Ar-Ruzz Media.

Ideham, S., et al. 2003. Sejarah Banjar. Banjarmasin: Badan Penelitian dan Pengembangan Daerah Propinsi Kalimantan Selatan.

Khairuzzaini. 2011. Islamisasi Kerajaan Banjar: Analisis hubungan Kerajaan Demak dengan Kerajaan Banjar atas Masuknya Islam di Kalimantan Selatan. Tesis. Program Studi Magister Hukum Islam UIN Sunan Kalijaga Yogyakarta. Tidak dipublikasikan.

Noor, Y. 2011. Islamisasi Banjarmasin. Tesis. Program Studi Magister Pendidikan IPS Universitas Lambung Mangkurat Banjarmasin. Tidak dipublikasikan.

Pires, T. 2014. Suma Oriental. Terj. Adrian Perkasa dan Anggita Pramesti. Yogyakarta: Penerbit Ombak.

Poesponegoro, M. D. dan Notosusanto, N. 1992. Sejarah Nasional Indonesia III. Jakarta: Balai Pustaka.

Ricklefs, M. C. 2009. Sejarah Indonesia Modern 1200-2008. Terj. Tim
Penerjemah Serambi. Jakarta: Serambi.

Suryanegara, A. M. 2009. Api Sejarah. Bandung: Salamadani.

Usman, A. G. 1995. Kerajaan Banjar: Sejarah Perkembangan Politik, Ekonomi Perdagangan dan Agama Islam. Banjarmasin: Lambung Mangkurat University Press.

Wikipedia. Moor. Diakses dari https:// id.wikipedia.org/wiki/Moor pada 14 November 2016. 